\title{
PENGARUH METODE BERNYANYI MELALUI MEDIA AUDIO VISUAL TERHADAP KETERAMPILAN BERBICARA ANAK KELOMPOK A TK TRIAMARTA KEDIRI TABANAN
}

\author{
Ni Luh Wayan Dina Widiani ${ }^{1}$, I Ketut Adnyana Putra ${ }^{2}$, Gusti Ngurah Sastra Agustika ${ }^{3}$ \\ 1,2,3 Jurusan Pendidikan Dasar \\ UniversitasPendidikanGanesha \\ Singaraja, Indonesia \\ e-mail dinawidiani839@gmail.com¹, ketut.adnyana.putra@undiksha.ac.id², \\ gn.sastra.a@undiksha.ac.id ${ }^{3}$
}

\begin{abstract}
Abstrak
Penelitian ini bertujuan untuk mengetahui perbedaan yang signifikan keterampilan berbicara anak yang dibelajarkan dengan metode bernyanyi melalui media audio visual dengan kelompok anak yang dibelajarkan dengan pembelajaran konvensional pada anak kelompok A TK Triamarta Kediri Tabanan Tahun Ajaran 2018/109.Desain penelitian ini adalah Penelitian Eksperimen semu dengan rancangan nonequivalent control group design.Populasi penelitian ini adalah seluruh anak kelompok A TK Triamarta Kediri Tabanan yang berjumlah 33 anak.Sampel diambil dengan teknik random sampling.Data yang diperoleh dianalisis menggunakan uji-t. Hasil analisis data diperoleh thitnung $=21,78$ sedangkan pada taraf signifikansi $5 \%$ dan $\mathrm{dk}=69$ diperoleh nilai ttabel $=2,0395$ sehingga thitung $=21,78>$ ttabel $=2,0395$. Berdasarkan kriterian pengujian, maka $H_{0}$ ditolak dan $H_{a}$ diterima. Adapun nilai rata-rata keterampilan berbicara anak pada kelompok yang dibelajarkan dengan metode bernyanyi melalui media audio visual adalah 75,56 , sedangkan pada kelompok yang dibelajarkan dengan pembelajaran konvensional adalah 51,24. Berdasarkan hasil tersebut dapat disimpulkan bahwa terdapat pengaruh metode bernyanyi melaluui media audio visual terhadap keterampilan berbicara anak kelompok A TK Triamarta Kediri Tabanan Tahun Ajaran 2018/2019.
\end{abstract}

Kata kunci: metode bernyanyi, media audio visual, keterampilan berbicara

\begin{abstract}
This study aims to determine the significant differences in children's speaking skills learned by the singing method through audio-visual media with groups of children taught with conventional learning in group $A$ children TK Tabanan Triamarta Kediri Academic Year 2018/109. The design of this study was a quasiexperimental study with a nonequivalent control group design. The population of this study were all children in group A TK Triamarta Kediri Tabanan, amounting to 33 children. The sample is taken by random sampling techniqueThe data obtained were analyzed using the t-test. The results of the data analysis were obtained $=$ 21.78 while at the $5 \%$ and $\mathrm{dk}=69$ significance levels obtained ttable $=2.0395$ so that $\mathrm{t}$ count $=21.78>\mathrm{t}$ table $=2.0395$. Based on the testing criteria, $\mathrm{H}_{-} \mathrm{O}$ is rejected and $\mathrm{H} \_\mathrm{a}$ is accepted. The average value of children's speaking skills in the group learned by the method of singing through audio visual media is 75.56 , whereas in the group that is taught by conventional learning is 51.24. Based on these results it can be concluded that there is an influence of the singing method through audio visual media on the speaking skills of children in group A TK Triamarta Kediri Tabanan Academic Year 2018/2019.
\end{abstract}

Keywords: singing method, audio visual media, speaking skill 


\section{PENDAHULUAN}

Pendidikan anak usia dini ialah individu yang berbeda, unik, dan memiliki karakteristik tersendiri sesuai dengan tahapan perkembangannya masing-masing (Suryaningsih, 2015). Masa anak usia dini di mulai dari usia 0-6 tahun atau sering disebut dengan masa keemasan (golden age) dimana pada masa ini, sangatlah penting untuk menstimulasi seluruh aspek perkembangan anak untuk tugas perkembangan selanjutnya.

Usia dini merupakan pondasi terbaik dalam mengembangkan kemampuan yang dimiliki anak untuk kehidupan di masa yang akan datang. Selain itu pendidikan di usia dini dapat mengoptimalkan kemampuan dasar anak dalam menerima proses pendidikan di usia-usia berikutnya. Pemberian pendidikan yang tepat pada masa ini berpengaruh sangat signifikan bagi prestasi belajar pada jenjang pendidikan berikutnya. Pendidikan anak usia dini dapat memberi peningkatan kualitas sumber daya manusia. Pada fase golden age ini anak mengalami perkembangan yang sangat pesat, baik menyangkut perkembangan fisik motoriknya, perkembangan moral Agama, perkembangan bahasa, perkembangan kognitif, sosial emosional dan pekembangan seni.

Perkembangan merupakan suatu perubahan yang berlangsung seumur hidup dengan bertambahnya struktur dan fungsi tubuh yang lebih kompleks dalam kemampuan gerak kasar, gerak halus, bicara dan bahasa serta sosialisasi dan kemandirian. Ciri-ciri pertumbuhan dan perkembangan anak antara lain, menimbulkan perubahan, memiliki hubungan yang erat dengan pertumbuhan, memiliki tahap yang berurutan dan mempunyai pola yang tetap. Salah satu perkembangan yang penting bagi anak adalah bahasa, dimana bahasa merupakan suatu bentuk komunikasi baik itu berupa lisan, tertulis atau isyarat. Kemampuan bahasa dapat dipelajari dan diperoleh anak melalui lingkungan, selain sebagai alat bersosialisasi, bahasa juga merupakan Menurut Rusniah (2016:116) bahwa "dalam perkembangan bahasa untuk anak usia dini meliputi empat perkembangan yaitu, mendengarkan, berbicara, membaca, dan suatu cara agar dapat merespon orang lain. Bromley (dalam Setyawan, 2016:92) mendefinisikan "bahasa merupakansistem simbol yang teratur untuk mentransfer berbagai ide maupun informasi yang terdiri dari simbol-simbol visual maupun verbal. Simbol visual tersebut dapat dilihat, ditulis, dan dibaca. Sedangkan simbol verbal hanya bisa diucap dan didengar".

Berbicara merupakan salah satu kemampuan berbahasa yang seharusnya dikembangkan pada anak usia dini. Kemampuan ini sangat erat kaitannya dengan kemampuan-kemampuan berbahasa lainnya seperti kemampuan menyimak dipadukan dengan kemampuan berbicara dengan cara mengungkapkan kembali apa yang didengar oleh anak. Pada anak usia dini (3-5 tahun) kemampuan berbahasa yang paling umum dan efektif dilakukan adalah kemampuan berbicara, hal ini sesuai dengan karakteristik umum kemampuan bahasa anak pada usia tersebut. Belajar berbicara dapat dilakukan anak dengan bantuan orang tuanya atau orang dewasa yang berada di sekitarnya, melalui percakapan anak mendapatkan pengalaman dan meningkatkan pengetahuannya serta mengembangkan bahasanya. Keterampilan berbicara sangat penting bagi anak. Hal tersebut dikarenakan keterampilan berbicara mampu membentuk anak menjadi penerus bangsa yang mampu melahirkan tuturan atau ujaran secara komunikatif, jelas dan runtut serta mudah dipahami. Memang setiap orang dikodratkan untuk berbicara secara lisan, tetapi tidak semua memiliki keterampilan untuk berbicara. Dalam melatih keterampilan berbicara, anak perlu dibiasakan untuk berinteraksi dengan orang lain, sehingga anak dapat menyampaikan pikiran dan perasaannya kepada orang lain. Oleh karena itu dalam penelitian ini anak diharapkan lancar dalam berkomunikasi sehingga dengan lancarnya berkomunikasi dan menyampaikan pesan dengan jelas maka dapat melatih keterampilan berbicara anak.

Permasalahan yang terjadi pada anak usia dini yaitu kurangnya keterampilan anak untuk berbicara, mereka seolah kehilangan imajinasi yang seharusnya banyak terdapat didalam pikiran mereka, atau mungkin saja mereka memiliki imajinasi namun mereka tidak mempunyai keberanian untuk mengungkapkannya. Keterampilan berbicara pada anak dapat 
dilatih melalui percakapan-percakapan yang dilakakukan oleh anak dengan orangtua, guru maupun dengan teman sebaya. Salah satu upaya yang dapat dilakukan khususnya di lingkungan sekolah agar kegiatan dalam meningkatkan keterampilan berbahasa terutama berbicara pada anak dapat terlaksana dan tujuan pembelajaran dapat tercapai secara optimal, maka diperlukan sebuah metode pembelajran dan media yang dapat membantu anak dalam meningkatkan keterampilan untuk berbicara, diantaranya adalah dengan menggunakan metode bernyanyi melalui media audio visual.

Umumnya anak-anak sejak dini diajak berbicara oleh orang tuanya sebagai bentuk pendidikan berbicara.Namun dalam pendidikan formal biasanya juga digunakan berbagai macam media pendukung dalam mengembangkan keterampilan berbicara anak, seperti buku bergambar, mendongeng, bercerita bahkan melihat dan mendengarkan sebuah nyanyian.Oleh karena itu aktivitas bernyayi memiliki fungsi yang sangat baik untuk pengembangan keterampilan berbicara pada anak.

Metode bernyanyi sangat berguna untuk melatih daya ingat anak, sehingga pengalaman dalam melafalkan secara terus menerus menjadikan memori ingatan jangka panjang (Gustiana, 2014). Namun keadaan tersebut yang bertentangan dengan harapan tidak jarang terjadi.Hal ini terjadi karena sangat jarang metode bernyanyi dijadikan suatu kegiatan yang digunakan untuk melatih berbicara pada anak karena selama ini bernyanyi hanya di gunakan untuk kegiatan seni semata.Penerapan metode bernyanyi yang dilakukan guru selama ini dalam meningkatkan kemampuan berbicara anak masih kurang maksimal antara lain, guru kurang menguasai cara bernyanyi yang benar sehingga irama yang dikeluarkan terdengar sumbang atau dapat dikatakan tidak sesuai dengan irama yang sebenarnya. Selain itu guru kurang menguasai lagu-lagu yang sesuai dengan tema yang akan diajarkan kepada anak, sehingga guru hanya menyanyikan lagu yang ia ketahui untuk tema-tema tertentu saja, dan jarang sekali menjelaskan arti nyanyian yang dinyanyikan tersebut dengan demikian kegiatan bernyanyi tidak berdampak positif atau baik pada keterampilan berbicara anak terdapat tujuh manfaat penggunaan lagu (menyanyi) dalam pembelajaran menurut Syamsyuri Jari (dalam Fadlillah, 2014) antara lain: 1) Sarana relaksasi dengan menetralisasi denyut jantung dan gelombang otak, dimana melalui lagu dapat membuat diri anak menjadi lebih tenang dalam prose pembelajaran. 2) Menumbuhkan minat belajar dan meningkatkan daya tarik dari setiap kegiatan pembelajaran yang diberikan oleh guru. 3) Menciptakan proses pembelajaran lebih humanis dan menyenangkan. 4) Sebagai jembatan dalam mengingat materi pembelajaran, karena melalui menyanyi secara tidak langsung anak akan mengucapkan kata-kata atau syair pada lagu secara berulang-ulangga sehingga mudah diingat oleh anak .5) Membangun retensi dan menyentuh emosi dan rasa estetika siswa. 6) Proses internalisasi nilai yang terdapat pada materi pembelajaran. 7) Mendorong motivasi belajar anak.

Berdasarkan uraian tersebut, secara teoretis metode bernyanyi berpengaruh terhadap keterampilan berbicara anak, tetapi secara empiris perlu dibuktikan melalui penelitian yang berjudul "Pengaruh Metode Bernyanyi Melalui Media Audio Visual Terhadap Keterampilan Berbicara Anak Kelompok A TK Triamarta Kediri Tabanan Tahun Ajaran 2018/2019". Berbicara adalah salah satu bagian terpenting dalam kehidupan, berbicara dapat membantu anak untung menyampaikan pesan atau gagasan yang ingin disampaikan kepada orang lain.Keterampilan berbicaradapat membantu anak agar dapat berkembang menjadi bertanggung jawab dan menjadi warga negara yang baik.

Berbicara adalah "sarana untuk membina saling pengertian komunikasi timbal balik, dengan meenggunakan bahasa sebagai medianya" (Ngalimun, 2014:55). Di dalam kelas kegiatan berbicara menggunakan bahasa yang mempunyai aspek komunikasi dua arah, yakni antara pembicara dengan pendengarnya secara timbal balik.Latihan berbicara harus terlebih dahulu didasari oleh: (1) kemampuan mendengarkan, (2) kemampuan mengucapkan, (3) penguasaan (relative) kosa kata. Secara umum tujuan latihan berbicara untuk tingkat pemula dan menengah, agar anak dapat berkomunikasi secara lisan dan sederhana dalam bahasa inggris. Oleh karena itu, dalam pembelajarannya harus mampu menggugah 
Menurut Jamaris (dalam Sya' Diyah, 2015)Salah satu alat komunikasi yang efektif adalah berbicara. Sesuai kebutuhan komunikasi, anak akan belajar untuk melakukan komunikasi dengan bahasa lisan atau bicara. Adapun aspek-aspek keterampilan berbicara pada anak yaitu. (1) KosakataSeiring dengan perkembangan dan pengalaman anak dalam berinteraksi dengan lingkungannya, kosakata pada anak akan berkembang dengan sangat pesat. (2) Sintak (tata bahasa) Walaupun anak belum mempelajaritata bahasa, akan tetapi melalui contoh-contoh berbahasa yang didengar dan dilihat anak di lingkungannya, anak telah dapat menggunakan bahasa lisan dengan susunan kalimat yang baik. (3) Semantik, Anak sudah dapat mengekspresikan keinginan, penolakan dan pendapatnya dengan menggunakan kata-kata dan kalimat yang tepat. (4) Fonen (bunyi kata) Anak sudah memilki kemampuan untuk merangkai bunyi yang di dengarnya menjadi satu kata yang mengandung arti.

Menurut (Fadlillah, 2014:175) Metode bernyanyi merupakan "metode pembelajaran yang menggunakan syair-syair yang dilagukan. Biasanya syair-syair tersebut disesuaikan dengan materi-materi yang akan diajarkan" sedangkan menurut Mulyani (2015:170), Menyanyi adalah sesuatu yang alamiah bagi anak. Anak-anak memang sangat suka menyanyi, walaupun ia tidak terlalu mengerti dengan makna dari lagu tersebut. Pengalaman menyanyi anak sejatinya adalah bentuk peniruan dari nyanyian ibu ketika menggendong atau hendak menidurkan, nyanyian kakak yang sedang menyapu, alunan musik dari radio dan televisi, suara-suara burung, ayam, dan sebagainya. Sama halnya anak belajar berbicara di awal pertumbuhannya. Anak adalah peniru yang baik, ia sangat senang meniru apa yang dilihat, didengar, dan dirasakan, selagi hal tersebut membuat mereka senang. Pendapat lain Menurut Suryaningsih (2015) Metode bernyanyi merupakan metode yang menggunakan unsur seni yang digemari oleh anak usia dini. Metode ini bukan termasuk metode baru dalam pembelajarn anak usia dini. Dalam kegiatan pembelajaran pada anak usia dini bernyanyi merupakkan kegiatan yang harus ada di setiap kegiatan pembelajaran, bahkan bernyanyi seolah -olah menjadi kegiatan yang wajib di lakukan setiap hari.

Menurut Riyanti (2015:11) disebutkan bahwa" dalam pembelajaran berbicara terdiri atas beberapa kegiatan berbicara antara lain percakapan, bercerita/ mendongeng, berbicara untuk menyampaikan informasi atau mempengaruhi dan kegiatan dramatik". 1) Percakapan, dalam hal melakukan sosialisasi dengan teman maupun guru, anak juga perlu mengadakan percakapan. Untuk itu anak perlu proses belajar bagaimana cara memulai sebuah percakapan dan dapat menjaga percakapan tetap dapat berjalan, anak juga harus tau caranya mengakhiri sebuah percakapan. 2) Bercerita, terdapat langkah-langkah dalam bercerita dalam pembelajaran bercerita, memilih cerita, menyiapkan diri untuk bercerita, dan penggunaan media dalam bercerita juga perlu agar cerita yang disampaikan lebih menarik. 3) Berbicara Untuk Menyampaikan Informasi atau Mempengaruhi Kegiatan bercerita yang termasuk dalam jenis ini yaitu melaporkan secara lisan, melakukan wawancara dan juga berdebat. 4) Kegiatan Dramatik Bermain peran merupakan salah satu media yang di gunakan oleh anak untuk melatih bahasa veral dan nonverbal dalam konteks yang bermakna.

Menurut Fadlillah (2014:176) menyatakan "bahwa sukses tidaknya penggunaan metode bernyanyi dalam pembelajaran sangat dipengaruhi oleh guru sendiri dan lagu yang dibawakannya". Bila guru pandai bernyanyi atau membawakan lagu, khususnya lagu anak-anak, tentu anak akan senang mendengar dan mengikutinya. Namun, bila dalam membawakan lagu sangat buruk, pasti anak akan merasa bosan dan bahkan malas mendengar, apalagi mengikutinya. Kemudian, untuk model lagunya, perlu dicari lagu yang sesuaidengan tema dan usia anak. Dalam pemilihan lagu jangan sampai memilih lagu orang dewasa. Karena lagu tersebut tidak sesuai dengan usianya, sehingga sulit dipahami oleh anak. Oleh karena itu, menggunakan metode bernyanyi dalam kegiatan pembelajaran, alangkah baiknya lagu yang dipilih sesuai dengan karakteristik usia anak. Agar anak-anak mudah mengerti dan memahami lagu yang dinyanyikan, baik dalam mengikutinya maupun mudah dalam mengambil makna-maknanya.

Dalam hal ini, media pembelajaran berperan untuk memberikan pengalaman belajar bagi anak, karena media pembelajaran merupakan alat secara fisik yang meliputi buku, tape recorder, kaset 
video kamera, videorecorder, film. Media pembelajaran juga mengandung materi instruksional di lingkungan anak yang dapat merangsang anak untuk belajar.Salah satu media yang dapat menarik perhatian anak adalah media audio visual. Pada saat sekarang ini, media elektronik sangat mampu menyebarkan berita sehingga mampu menarik minat penonton terutama anakanak.Tidak jarang anak-anak lebih suka berlama-lama didepan televisi dari pada belajar. Untuk mensiasati kemajuan teknologi sekarang dapat dimanfaatkan sebagai media pembelajaran untuk mengembangkan ketrampilan berbicara anak yaitu salah satunya dengan memberikan tontonan melalui media audio visual dengan acara-acara animasi kartun atau slide kartun yang berorientasi pada pendidikan pengembangan ketrampilan berbicara anak.

Menurut Wati (2016:46) media audio visual adalah "media yang dapat menampilkan unsur suara dan gambar. Gabungan dari kedua unsur tersebut menjadikan media audio visual memiliki kegunaan yang lebih baik dari media pembelajaran lainnya". Sedangkan pendapat lain dari Setyawan (2016) Media audio visual adalah media kombinasiantara audio dan visual yang dikombinasikandengankaset audio yang memilikiunsursuara dan gambar yang bisadilihatlangsung, sepertirekamam video, berbagaiukuran film, slide suara dan lain sebagainya. Media audio visual sangatlah baik digunakan untuk pembelajaran anak.Sebab, media ini telah memadukan antara media pendengaran dan penglihatan. Dengan menggunakan media ini anak akan lebih mudah dalam memahami materi pembelajaran yang diberikan. Menurut Hasan (2016:26) menyatakan kelebihan media audio visual adalah "pemakaiannya tidak membosankan, hasilnya lebih mudah untuk dipahami, dan informasi yang diterima lebih jelas dan cepat dimengerti".

Menurut Wati (2016) media audio visual memiliki beberapa kegunaan yaitu media audio visual merupakan salah satu jenis media yang dianggap memiliki kemampuan lebih baik dan menarik. Dalam hal ini, media adio visual yang digunakan yaitu film atau video. Film merupakan sebuah gambar dalam frame dimana frame demi frame diproyeksikan melalui lensa proyektor secara mekanis. Sehingga gambar pada layar terlihat hidup. Film bergerak dengan cepat dan bergantian sehingga memberikan visual yang kontinyu.Selain sebagai hiburan, dokumentasi dan hiburan, media audio visual juga dapat menyajikan informasi, memaparkan proses, menjelaskan konsep-konsep yang rumit, mengajarkan keterampilan, juga dapat menyingkat dan memperpanjang waktu dan mempengaruhi sikap.

Adapun tujuan dalam penelitian ini Sesuai dengan latar belakang dan rumusan masalah tersebut, maka tujuan penelitian ini adalah sebagai berikut.Untuk mengetahui pengaruh yang signifikan penerpan metode bernyanyi melalui media audio visual terhadap keterampilan berbicara anak kelompok A TK Triamarta Kediri Tabanan Tahun Ajaran 2018/2019.

\section{METODE HASIL DAN PEMBAHASAN}

Penelitian ini dilaksanakan pada bulan januari sampai dengan bulanMei 2019. Pada kelompok $A$ TK Triamarta Kediri Tabanan tahun ajaran 2018/2019. Yang terdiri dari kelompok A1 dan kelompok A2 TK Triamarta Kediri Tabanan.Adapun waktu penelitian ini dilaksanakan pada bulan Januari sampai dengan bulan Mei 2019. Jenis penelitian yang dilakukan dalam penelitian ini adalah penelitian eksperimenyaitu quasi eksperiment (eksperimen Semu). Desain eksperimen yang digunakan adalah "Nonequivalent Control Group Design".Pre-test diberikan untuk kelompok kontrol dan kelompok eksperimen. Pemberian pre test biasanya digunakan untuk mengukur equivalensi atau penyetaraan kelompok. Setelah itu diberikan perlakuan, yaitu dengan memberikan metode pembelajaran bernyanyi kepada kelompok eksperimen. Kemudian setelah diberikan perlakuan, dilakukan post-test untuk mengetahui keterampilan berbicara.

Populasi bukan sekedar jumlah yang ada pada objek atau subjek yang dipelajari, tetapi meliputi seluruh karakteristik atau sifat yang dimiliki oleh objek atau subjek itu.Menurut Agung (2014:69), "populasi merupakan keseluruhan objek dalam suatu penelitian". Populasi dalam penelitian ini adalah seluruh anak kelompok A TK Triamarta Kediri Tabanan yang keseluruhan 
berjumlah 33 orang anak. Dari populasi yang telah ditentukan maka selanjutnya mengambil perwakilan dari populasi yang dianggap mewakili seluruh populasi yaitu sampel. Dalam penelitian ini sampel yang dipilih adalah dua kelompok yaitu satu kelompok dijadikan kelompok eksperimen dan satu kelompok dijadikan sebagai kelompok control. Kedua kelompok tersebut diberikan perlakuan yang berbeda, satu kelompok diberikan perlakuan dengan menggunakan pemberlajaran metode bernyanyi dan satu kelompok lagi diberikan perlakuan dengan pembelajaran konvensional.

Pengambilan sampel dalam penelitian ini menggunakan teknik random sampling yang dilakukan dengan cara pengundian. Dari hasil pengundian jika sudah terpilih dua kelompok, maka kelompok yang tepilih diberikan pre-test yang bertujuan untuk menyetarakan kelang dengan menggunakan uji-t, uji prasayarat yang meliputi uji normalitas dan uji homogenitas varian yang dilakukan terlebih dahulu dilakukan sebelum dilakukan uji-t. setelah kedua kelompok tersebut dikatakan setara, selanjutnya dilakukan pengundian kembali untuk menentukan kelompok yang dijadikan sebagai kelompok eksperimen dan kelompok control. Setelah dilakukan pengundian, kelompok yang terpilih sebagai kelompok eksperimen adalah kelompok A1 TK Triamarta Kediri Tabanan dan kelompok yang terpilih sebagai kelompok control adalah A2 TK Triamarta Kediri Tabanan. Setelah kedua kelas yang terpilih maka dilakukan uji kesetaran untuk mengetahui tingkat kesetaraan kedua kelas yang akan dijadikan kelas eksperimen dan kelas kontrol. Apabila kedua kelas sudah setara maka dilakukan pengundian tahap kedua untuk menentukkan kelas eksperimen dan kelas kontrol. Untuk menguji hipotesis kesetaraan sampel digunakan uji-t, Berdasarkan perhitungan hasil uji normalitas sebaran data nilai pre-test Kelompok eksperimen $X^{2}$ hitung $=3,953$ dan $X_{\text {tabel }}^{2}=5.991$, karena $X^{2}{ }_{\text {hitung }}<X^{2}$ tabel makadata berdistribusi normal.Sedangkan perhitungan hasil uji normalitas nilai pre-testKelompok kontrol diperoleh $X^{2}$ hitung $=4,438$ dan $X^{2}$ tabel $=$ 5.991. Karena $X^{2}$ hitung $<X^{2}$ tabel makadata berdistribusi normal.

Setelah uji normalitas dilakukan diperoleh kedua kelas sampel bersistribusi normal, maka uji homogenitas dapat dilakukan. Uji homogenitas varian data hasil pre-test keterampilan berbicara anak dilakukan dengan menggunakan uji $F$.Berdasarkan hasil uji homogenitas varians $F_{\text {hitung }}=1,09$ dan $F_{\text {tabel }}=4.16$, karena $F_{\text {hitung }}<F_{\text {tabel }}$ maka data homogen.

Karena data nilai pre-test kedua kelas sampel berdistribusi normal dan homogen, maka dilanjutkan dengan melakukan uji kesetaraan dengan uji-t. Berdasarkan hasil analisis didapatuji-t diperoleh $\mathrm{t}_{\text {hitung }}=0,317$ dan $\mathrm{t}_{\text {tabel }}=$ dengan $\mathrm{dk}=(\mathrm{n} 1+\mathrm{n} 2-2)=31$ dengan taraf signifikan $5 \%=$ 2,0935. Dengan demikian harga $t_{\text {hitung }}<t_{\text {tabel }}=0,317>2,0935$, maka Ho diterima sehingga pre-test kontrol dan pre-test eksperimen setara.Setelah diketahui kedua kelompok sampel setara, kemudian dilakukan pengundian yang kedua untuk menentukan kelas ekperimen dan kelas kontrol. Setelah dilakukan random maka kelas yang terpilih untuk menjadi kelompok eksperimen adalah kelompok A1 Untuk kelas kontrol terpilih kelompok A2

Metode pengumpulan data yang digunakan dalam penelitian ini adalah dengan metode non tes dalam bentuk lembar observasi keterampilan berbicara anak. Agung (2016:94)menyatakan bahwa "observasi adalah suatu cara untuk mengadakan penilaian dengan jalan mengadakan pengamatan secara langsung dan sistematis".Lembar observasi yang digunakan untuk mengukur keterampilan berbicara anak berupa kisi-kisi instrument penelitia. Observasi yang dilakukan menggunakan checklist dengan 4 pilihan Belum Berkembang (BB), Mulai Berkembang (MB), Berkembang Sesuai Harapan (BSH), Berkembang Sangat Baik (BSB).

Data keterampilan berbicara anak adalah data hasil dari post-test yang diberikan setelah perlakuan. Data tersebut kemudian dianalisis dengan metode analisis statistik.Metode analisis statistik dapat dibagi menjadi dua, yaitu statistik deskriptif dan statistik inferensial

Stasistik deskripitf menurut Sugiyono, 2011:207)adalah "ststistik yang digunakan untuk menganalisis data dengan cara mendeskripsikan atau menggambarkan data yang telah terkumpul sebagaimana adanya tanpa bermaksud membuat kesimpulan yang berlaku untuk umum atau generalisasi".Adapun data yang disajikan dalam statistik deskriptif adalah perhitungan mean, standar deviasi dan varians.

"Statistik inferensial adalah adalah teknik statistik yang digunakan untuk menganalisis data sampel dan hasilnya diberlakukan untuk populasi” (Sugiyono, 2011:106). 
Statistik inferensial teridiri dari pengujian prasyarat analisis dan pengujian hipotesis.Sebelum dilakukan uji hipotesis, terlebih dahulu dilakukan uji prasyarat analisis data. Uji prasyarat yang dilakukan dalam penelitian ini adalah uji normalitas dan homogenitas. Uji Normalitas dimaksudkan untuk mengetahui apakah sebaran data skor keterampilan berbicara anak masing-masing kelompok berdistribusi normal atau tidak sehingga dapat menentukan teknik analisis datanya. Uji Normalitas sebaran data dalam penelitian ini menggunakan Chi-kuadrat. Kriteria pengujian adalah jika $X_{\text {Hit }}^{2}<X_{\text {tabel }}^{2}$ maka $h_{\circ}$ diterima (gagal ditolak) yang berarti data berdistribusi normal. Sedangkan taraf signifikansinya adalah $5 \%$ dan derajat kebebasannya $n-1$.Uji Homogenitas dilakukan untuk menunjukkan bahwa perbedaan yang terjadi pada uji hipotesis benar-benar terjadi akibat adanya perbedaan varians antar kelompok, bukan sebagai akibat perbedaan dalam kelompok. Uji homogenitas dapat dilakukan apabila kelompok data tersebut berdistribusi normal. Uji homogenitas varians dilakukan dengan uji F. Kriteria pengujian, jika $F_{\text {hit }}<F_{\text {tabel }}$ maka sampel homogen. Analisis data dalam penelitian ini menggunakan uji beda mean (uji t) dengan rumus polled varians. Dengan kriteria jika harga thitung $\leq t_{\text {tabel, }}$ maka Ho diterima dan Ha ditolak, dan jika harga $t_{\text {hitung }}>t_{\text {tabel }}$ maka Ho ditolak dan Ha diterima. Pada taraf signifikan $5 \%$ dengan $d k=n 1+n 2-2$.

Berdasarkan hasil analisis statistik deskriptif keterampilan berbicara kelompok eksperimen diperoleh $\mathrm{X}^{-}=75,56$ dan rerata persentase keterampilan berbicara kelompok eksperimen $75,56 \%$. Rerata persentase keterampilan berbicara tersebut kemudian dikonversikan pada tabel PAP skala lima, sehingga dapat diketahui keterampilan berbicara anak kelompok eksperimen berada pada kategori sedang.

Sedangkan hasil analisis statistik deskriptif kompetensi keterampilan berbicara kelompok kontrol diperoleh $\bar{X}=51,24$ dan rerata persentase keterampilan berbicara kelompok kontrol adalah $51,24 \%$. Rerata persentase keterampilan berbicara tersebut kemudian dikonversikan pada tabel PAP skala lima, sehingga dapat diketahui keterampilan berbicara anak kelompok kontrol berada pada kategori sedang.Sesuai dengan hasil analisis data keterampilan berbicara menunjukkan bahwa rata-rata keterampilan berbicara anak kelompok eskperimen lebih dariratarata keterampilan berbicara anak kelompok kontrol ( $\bar{X}=75,56>\bar{X}=51,24)$.

Tabel 1

Rangkuman Statistik Deskriptif Variabel Penelitian

\begin{tabular}{|l|c|c|c|c|}
\hline \multirow{2}{*}{ Statistik Variabel } & \multicolumn{2}{|c|}{ Kontrol } & \multicolumn{2}{c|}{ Eksperimen } \\
\cline { 2 - 5 } & Pre-Test & Post-Test & Pre-Test & Post-Test \\
\hline N & 17 & 17 & 16 & 16 \\
\hline Mean & 48,41 & 51,24 & 49,06 & 75,56 \\
\hline Median & 50,00 & 50,00 & 50,00 & 75,00 \\
\hline Modus & 50 & 50 & 50 & 75 \\
\hline Standar Deviasi & 6,011 & 5,093 & 5,767 & 3,983 \\
\hline Varians & 36,132 & 25,941 & 33,263 & 15,863 \\
\hline Range & 21 & 18 & 21 & 12 \\
\hline Minimum & 38 & 41 & 38 & 69 \\
\hline Maksimum & 59 & 59 & 59 & 81 \\
\hline Sum & 823 & 871 & 785 & 1209 \\
\hline
\end{tabular}


Histogram Perbandingan data Pre-Test dan Post-Test

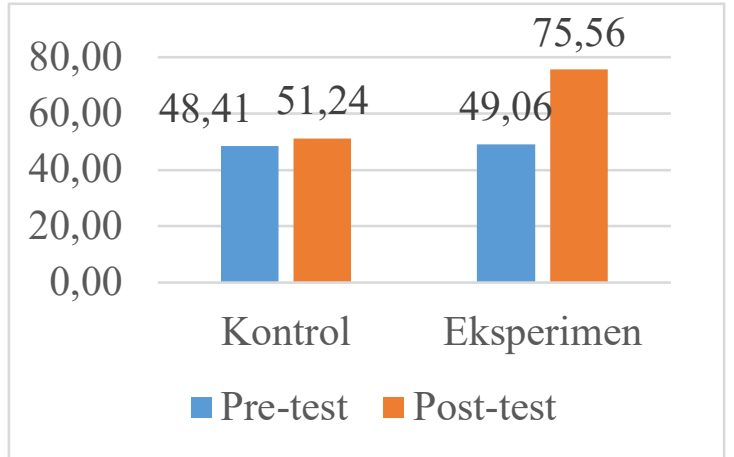

Tabel 2.

\begin{tabular}{|l|c|c|c|c|}
\hline \multicolumn{5}{|c|}{ Rekapitulasi Statistik Gain Score Pre-Test Kontrol dan Gain Score Post-Test } \\
EksperimenGroup Statistics
\end{tabular}

Hasil analisis uji $\mathrm{t}$ diperoleh $\mathrm{t}_{\text {hitung }}=21,78$. Harga tersebut kemudian dibandingkan dengan harga $t_{\text {tabel }}$ dengan $d k=16+17-2=31$ dan taraf signifikansi $5 \%$ sehingga diperoleh harga $t_{\text {tabel }}=2,0395$, karena $t_{\text {hitung }}>t_{\text {tabel }}$ maka $\mathrm{Ho}$ ditolak atau $\mathrm{Ha}$ diterima. Hal ini berarti terdapat perbedaan yang signifikan keterampilan berbicara anak kelompok eksperimen dan anak kelompok kontrol.

Rata-rata keterampilan berbicara kelompok eskperimen lebih darirata-rata keterampilan berbicara kelompok kontrol $(\bar{X}=75,56>\bar{X}=51,24)$. Sehingga dapat disimpulkan bahwa penerapan metode bernyanyi melalui media audio visual bepengaruh terhadap keterampilan berbicara anak kelompok A TK Triamarta Kediri Tabanan Tahun Ajaran 2018/2019.

Penelitian ini menguji pengaruh metode bernyanyi melalui media audio visual terhadap keterampilan berbicara anak kelompok A TK Triamarta Kediri Tabanan Tahun Ajaran 2018/2019 pada tema alam semesta. Sebelum dilakukan uji hipotesis statistik dengan menggunakan analisis uji-t, dilakukan uji prasyarat yang meliputi uji normalitas sembarang data dan uji homogenitas varian. Dari hasil perhitungan sebaran data hasil post-tespada kedua kelompok berdistribusi normal dan memiliki varian homogen. Karena data ada kelompok eksperimen dan kelompok kontrol telah memenuhi semua syarat, selanjutnya dilakukan analisis menggunakan uji-t.

Rata-rata keterampilan berbicara anak kelompok eksperimen lebih dari rata-rata kelompok kontrol $\left(X^{-}=75,56>X^{-}=51,24\right)$. Sehingga dapat disimpulkan bahwa penerapan metode berny.

Dari perolehan nilai kompetensi keterampilan berbicara pada kedua kelompok dapat diketahui bahwa kedua kelompok yang awalnya memiliki kemampuan setara melalui media audio visual berpengaruh terhadap keterampilan berbicara anak kelompok A TK Triamarta Kediri Tabanan Tahun Ajaran 2018/2019. setelah diberikan perlakuan yang berbeda, perolehan nilai keterampilan berbicara mengalami perbedaan. Keterampilan berbicara anak kelompok eksperimen lebih baik daripada kelompok kontrol .

Perbedaan keterampilan berbicara anak kelompok eksperimen dan kelompok kontrol terjadi karena perbedaan pemberian perlakuan yamg diberikan saat pembelajaran. Kelompok ekspeimen diberikan pembelajaran dengan menerapkan metode bernyanyi melalui media audio visual memiliki nilai rata-rata yang lebih tinggi dibandingkan kelompok kontrol yang tidakmenerapkan model pembelajran metode bernyanyi. 
Penerapan metode bernyanyi melalui media audio visualdapat meningkatkan faktor-faktor yang mempengaruhi keterampilan berbicara anak. Minat belajar anak dapat dipengaruhi melalui kegiatan nonton bersama bernyanyi sembari melihat gambar yang ditampilkan pada slide.

Berbeda dengan keterampilan berbicara anak dikelompok kontrol yang tidak menerapkan metode bernyanyi melalui media audio visual.Anak terlihat tidak semangat dan antusia dalam mengikuti pembelajaran. Proses pembelajaran yang kurang mnyenangkan membuat anak merasa bosan sehingga sulit untuk memahami materi pembelajaran.

Peenlitian ini diperkuat dengan penelitian yang relevan, yang dilakukan Penelitian yang dilakukan oleh Ariestyawati (2013) dengan judul "Peningkatan Keterampilan Berbicara Menggunakan Media Audio Visual Pada Siswa Kelas II'.Penelitian ini menggunakan pendekatan penelitian tindakan kelas yang dilaksanakan di kelas II Sekolah Dasar Negeri 14 Pontianak Utara.Pada siklus pertama dijelaskan bahwa dari aspek kebahasaan $48 \%$ anak dinilai cukup baik dan aktif dalam berbicara dan $40 \%$ dianggap cukup baik dalam berbicara. Pada siklus kedua semua anak dapat kesempatan berbicara dari aspek kebahasaan $68 \%$ dinilai baik dan aktif dalam berbicara, dari aspek nonkebahasaan $60 \%$ anak di nilai baik dalam berbicara. Dan pada siklus ketiga dari $88 \%$ anak dari aspek kebahasaan dinilai sudah baik dan aktif berbicara, dari aspek nonkebahasaan $80 \%$ anak sudah dinilai baik dalam berbicara.

Penelitian ini juga di perkuat oleh hasil penelitian Penelitian yang dilakukan oleh Sa'adah (2014) dengan judul "Mengembangkan Kemampuan Berbicara Melalui Metode Bernyanyi Pada Anak Usia 3-4 Tahun PAUD Anggrek Desa Sukodono Kecamatan Karangrejo Kabupaten Tulungagung Tahun Ajaran 2014/2015.Penelitian ini menggunakan pendekatan tindakan kelas dengan subjek penelitian anak didik PAUD Anggrek Sukodono.Penelitian ini dilakukan dalam 3 siklus. Pada siklus pertama nilai anak masih rendah, dimana dari 12 anak $25 \%$ mendapat bintang satu, $17 \%$ mendapat bintang dua, 33\% mendapat bintang tiga dan $25 \%$ mendapat bintang empat. Pada siklus kedua kriteria keberhasilan bila dilihat dari ketuntasan belajar anak mencapai $70 \%$ dari keseluruhan, dari 12 anak $17 \%$ mendapat bintang satu, 17\% mendapat bintang dua, 33 $\%$ mendapat bintang tida dan 33\% mendapat bintang empat.Pada siklus ketiga juga kriteria keberhasilan mencapai $70 \%$ dari jumlah anak, dari 12 anak $0 \%$ mendapat bintang sati, $17 \%$ mendapat bingtang dua, 55\% mendapat bintang tiga, dan $33 \%$ mendapat bintang empat.

\section{PENUTUP}

Berdasarkan analisis dan hipotesis yang diperoleh dapat disimpulkan bahwa metode bernyanyi melalui media audio visual berpengaruh terhadap keterampilan berbicara anak kelompok A TK Triamarta Kediri Tabanan Tahun Ajaran 2018/2019. Hal ini terbukti dari rerata kelompok yang dibelajarkan menggunakan metode bernyanyi melalui media audio visual sebesar $\bar{X}=75,56$ sedangkan pada keterampilan berbicara anak yang dibelajarkan melalui pembelajaran konvensional pada anak kelompok control diperoleh rata-rata sebesar $\bar{x}=51,24$. Rerata keterampilan berbicara yang diperoleh pada anak yang dibelajarkan dengan metode bernyanyi melalui media audio visual lebih tinggi daripada anak yang dibelajarkan dengan pembelajaran konvensional. Berdasarkan analisis data dengan menggunakan uji-t diperoleh $t_{\text {hitung }}=21,78$ dan $t_{\text {tabel }}$ $=$ dengan $\mathrm{dk}=(\mathrm{n} 1+\mathrm{n} 2-2)=31$ dengan taraf signifikan $5 \%=2,0395$. Dengan demikian harga $t_{\text {hitung }}>t_{\text {tabel }}=21,78>2,0395$, hal ini berarti terdapat pengruh metode bernyanyi melalui media audio visual terhadap keterampilan berbicara anak kelompok A TK Triamarta Kediri Tabanan Tahun Ajaran 2018/2019.

Berdasarkan hasil penelitian, pembahasan dan simpulan maka dapat diajukan beberapa saran kepada beberapa pihak sebagai berikut.Bagi guru, hasil penelitian ini bisa dijadikan acuan merancang pembelajaran yang menyenangkan membangitkan keaktifan anak. Khususnya guru yang mengajar di kelompok A di sarankan untuk mengembangkan inovasi pemeblajaran dengan menerapkan strategi, pendekatan,model, dan metode yang mampu mengoptimalkan aspek perkembangan anak. Selain itunguru agar lebih kreatif untuk memberikan fasilitas berupa sumber belajar dan kesempatan yang lebih besar bagi anak pada pembelajaran enggan menggunakan metode bernyanyi sehingga dapat tercipta pembelajaran bermakna dan menyenangkan bagi siswa.Berdasarkan simpulan dari penelitian ini, maka hasil penelitian ini dapat dipakai kajian 
penelitian relevan yang bermanfaat oleh peneliti lain untuk meneliti tentang pengaruh metode bernyanyi melalui media audio visual terhadap keterampilan berbicara.

\section{DAFTAR RUJUKAN}

Agung, A. A. G. (2016). Statistika Dasar untuk Pendidikan. Yogyakarta: Deepublish.

Ariestyawati, R. (2013). Peningkatan Keterampilan Berbicara Menggunakan Media Audiovisual Pada Siswa Kelas II.

Fadlillah, M. (2014). Desain Pembelajaran PAUD. Yogyakarta: AR-RUZZ MEDIA.

Hasan, H. (2016). Penggunaan Media Audio Visual Terhadap Ketuntasan Belajar IPS Materi Perkembangan Teknologi Produksi, Komunikasi, dan Transportasi Pada Siswa Kelas IV SD Negeri 20 Banda Aceh.

Mulyani, N. (2015). Dasar- Dasar Pendidikan Anak Usia Dini. Yogyakarta: Kalimedia.

Ngalimun. (2014). Pembelajaran Keterampilan Berbahasa Indonesia. Yogyakarta: Aswaja Pressido.

Rusniah. (2016). MeningkatkanPerkembangan Bahasa Indonesia Anak Usia Dini Melalui Penggunaan Metode Bercerita Pada Kelompok A Di TK Malahayati Neuhen Tahun Peelajaran 2015/2016.

Setyawan, F. H. (2016). Meningkatkan Kemampuan Berbahasa Anak Usia dini Melalui Model Pembelajaran Audio Visual Berbasis Android. Jurnal PG-PAUD Trunojoyo, 3(2).

Sugiyono. (2011). Metode Penelitian Pendidikan : Pendekatan Kuantitatif, kualitatif, dan R\&D. Bandung: Alfabeta.

Suryaningsih. (2015). Pengaruh Metode Bernyanyi Terhadap Perkembangan Bahasa Anak Usia Dini Di Lemaga PAUD Melati II Madiun Tahun Ajaran 2015/2016.

Sya' Diyah, F. (2015). Peningkatan Keterampilan Berbicara Anak Usia 3-4 Tahun Melalui Metode Bercerita (Wayang Beber Tematik) Di Kelompok Bermain Al- Jauhariyyah Muslimat Nu Kajen Margoyoso Pati.

Wati, E. R. (2016). Ragam Media Pembelajaran. Kata Pena. 